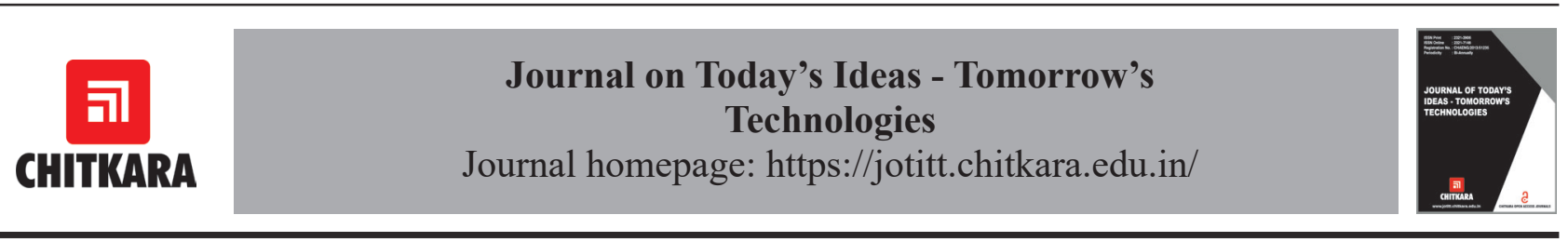

\title{
Migration to Online Teaching-Learning in School Education during COVID-19
}

\author{
Tabasum Mirza ${ }^{1}$ and Malik Mubasher Hassan*2 \\ ${ }^{1}$ District Institute of Education and Training (DIET), Rajouri, $J \& K-185234$, India \\ ${ }^{2} B G S B$ University, Rajouri, $J \& K$ - 185234, India \\ *mubasher2003@gmail.com (Corresponding Author)
}

\section{ARTICLE INFORMATION}

Received: January 5, 2021

Revised: March 19, 2021

Accepted: April 2, 2021

Published Online: June 22, 2021

Keywords:

Online learning, COVID-19, School

closures, ICT

\begin{abstract}
Prolonged school closures due to COVID-19 pushed the education system at all levels of India to the limits where structural weaknesses and other loopholes can be clearly visible. The significant challenges like lack of ICT infrastructure and digital competence of teachers, played an important role in the acceptance of new modes of teaching. Creating and delivering the educational content by using digital tools still remains a daunting task for many teachers. At the same time parents are overwhelmed with the burden to teach children at home and help them with online learning and bearing extra expenses of digital devices and internet services. Students, on the other hand, are struggling continually to adapt to a new learning environment that offers some flexibility along with some challenges. This study aims to present the challenges faced in instant migration of offline to online mode of teaching-learning by the stakeholders.
\end{abstract}

\section{Introduction}

The COVID-19 pandemic initially paralyzed all the spheres of human development. The world economy has been badly affected due to the abrupt closure of minor as well as major industrial, manufacturing, communication, entertainment, tourism, businesses and other forms of the economic activities. One of the important sectors, which are also severely affected all across the globe, is the education sector.

The world has reported 80,306,622 COVID-19 cases and 1,759,690 fatalities resulting from COVID-19 till date. India has reported a total of $10,172,777$ cases of COVID-19 and 147415 deaths due to COVID-19 as on 26 December 2020 [1]. The COVID-19 infection emerged as a flu-like disease in the Wuhan city of China in December 2019. On 30 January 2020 WHO declared it as an international public health emergency and then
COVID-19 outbreak was declared as a global pandemic on 11 March 2020[2].

In response to the recommendations of $\mathrm{WHO}$ to practice social distancing to contain the spread of virus different countries imposed lockdowns, orders to stay at home or restrictions on the free movement of general public to manage the spread of COVID-19. The schools were closed in almost 80 countries of the world affecting almost $61.6 \%$ of the total student population around the world. India also closed all the educational institutions on March 16, 2020 to control the spread of COVID-19 infection [3]. It has been more than nine months from the date and educational activities in schools are still at halt in India.

In response to school closures and to minimize the loss of learning caused to millions of students worldwide due to COVID-19 crisis UNESCO emphasized and supported countries in moving to remote mode of 
learning i.e. e-learning [4, 5].

The COVID-19 pandemic has thrusted long term effect on the education sector which has never been witnessed in history. COVID-19 has affected education at all the levels from kindergarten to University leading to worldwide closure of educational institutions. According to UNESCO reports 300 million students have suffered loss to education because of temporary school closures to contain the spread of COVID-19 infection. This constitutes the $91 \%$ of the world's student population and hence is a major concern worldwide that needs to be addressed.

According to UNESCO reports, the education of 247 million school children is affected in India because of school closures due to COVID-19 (UNICEF report). Prolonged school closure because of COVID-19 will increase the dropout rates in education because some of the children will never return to the school again especially girl students $[6,7]$. It is projected that as per the latest UN Report, 24 million children may drop out of schools due to school closures resulting out of COVID-19. The main reason behind this is the economic fallout caused by COVID-19 [8].

UNESCO stressed on the use of alternative modes of learning using technological framework, i.e. online mode of learning to combat the loss of learning that has occurred to learners because of school and university closures. COVID-19 has led to the sudden and unprecedented digital transformation of the education system in India leaving no other option for educators than to move to online mode[ $[9,10]$.

In developing countries like India the transition to online mode of learning was not easy because of insufficient digital infrastructure and lack of familiarity.

Teacher preparedness, presence of technological infrastructure and availability of high speed internet access are the main challenges faced by the stakeholders to switch from classroom teaching to online mode possible mainly related to designing and organising for better learning experiences and creating distinctive learning environments, with the help of digital technologies [11]. With this article, we provide some expert insights into this online-learningrelated Pedagogical Content Knowledge (PCK), with the goal of helping non-expert university teachers (i.e. those who have little experience with online learning $[12,13]$.

Most of the students and teachers are using online learning mode for the first time and are facing challenges in using virtual platforms. Students who are digitally literate or have technological background are facing less problems in accessing the online platforms of learning, resources of learning[14,15]. Teachers who are not digitally literate or have little or no computer knowledge are facing technical issues in creation, dissemination and presentation of digital content. There is a lack of prerequisite knowledge and skills about the use of online modes of learning in teachers and students. Teachers and students at first were skeptical about the use of digital platforms as main source of teaching/learning, but as the time passed on things are changing. Although it took some time for teachers to get accustomed to this new mode of instruction and teachers throughout the world worked hard to make this transition from classroom teaching to a virtual classroom worthwhile. Older generation teachers are not familiar with technology and thus struggle continuously with this new mode of teaching particularly with the use of sophisticated teaching tools which may not be user friendly [16-19].

Teachers have to put lot of effort and time is required to prepare, disseminate and deliver digital content. Lack of digital literacy skills has put teachers in the challenging situation where they are left with no other choice but to adapt themselves to a new teaching environment particularly for teachers lacking computer skills. Teachers of primary classes and younger children keep on experimenting with strategies to design interactions suitable to help connect students via virtual platforms and prepare daily assignments to keep students engaged at their respective places[20].

Online teaching/learning is evolving and educators are experimenting with different strategies, techniques, platforms to suit their needs, custom sizing existing teaching pedagogies and methods to create effective online teaching pedagogies to engage learners in the best possible manner[21-23].

There is a huge digital divide in India because of the disproportionate availability of smart phones, devices, internet access throughout the country. Poor people lack access to digital infrastructure like smart phones, electricity and high speed internet connectivity making it difficult for them to participate in the global network of technology. Although the Govt of India has taken many initiatives to bridge the digital divide but almost 400 million people still have no internet access thus depriving them of basic rights like right to education [24]. COVID-19 has broadened the digital divide as educational institutions are forced to completely digitize the teaching/learning process to ensure social distancing reducing the opportunities of learning to already disadvantaged sections of the society in the country. Some disadvantaged children are left out of the online education process because of spatial digital divide and some because of gender digital divide i.e. less women having access to technology than men[25].

Devices used for accessing e-learning platforms or attending sessions play an important determinant role in user friendliness and effectiveness of sessions attended by students and delivered by teachers. 
Online learning has put an extra burden on parents who have to assist their children during the learning process, particularly in the case of young children who cannot operate digital devices without the help of parents and cannot understand online classes on their own. It has also resulted in extra investment and increased costs on the part of parents/children in terms of computer devices, mobile phones, internet packs, web based tools $\operatorname{etc}[26]$.

Parents are worried about the increased screen time of children by excessive use of devices like smart phones for online learning which according to healthcare experts can increase the risk of onset and progression of myopia and other health problems in children. Parents and educationists fear that children, particularly teenagers misuse cell phones, digital devices and indulge in cyber crimes like cyber bullying, creating fake social media accounts, uploading/downloading of pornographic or violent content provided to them for the purpose of online learning. With a spike in the number of digital fraud cases and online scams like phishing, some fraudsters find it easy to lure children and grab money from them online by sending anonymous friend requests and asking credentials about the bank accounts, credit cards etc making them easily fall prey to scammers [27, 28].

The shifting was not an easy task with regard to its implementation. There are several issues and challenges, which are the hurdles in the smooth conduct of online teaching-learning. Although the concept of online mode of learning came into existence long back to ensure easy and cost effective access by every interested learner of the globe. The other reasons to develop an online learning mode are:

- It is the integral and most important component of Digital Literacy, which is one of the millennium goals

- Right to education

- Dissemination of knowledge to every interested learner

- Globalization of knowledge

- Faculty delivered instructions via the internet

- Access the education across the borders irrespective level of the financial health of the learner

The online teaching has not only brought new challenges for the students, but it has also put the teachers on the verge to rethink and redefine their role. The offline teaching is predominantly known for teacher centric. The online mode of learning is generally divided into two types, Asynchronous and Synchronous mode of learning. Asynchronous mode, where both the teacher and student are online at the same time and it is the teachers who actually control the time of contact. In synchronous mode of learning, the students and teachers are not in synchronous with respect to the time and the student access the stored content available on the cloud servers. The major portion of the online mode of teaching is asynchronous, which is student centric. The maintenance of a healthy student teacher relationship needs to be unfreeze, modified and refreeze to maintain the sanctity of the teacher position in the educational institutions. The teacher has to take the assignment of creation and delivery of e-content in a very professional and rigorous manner, so that this generated content can shed lasting impression on the students' personality and the respect for a teacher is improved in the eyes of a student. This concept of developing best e-content by the teachers is of paramount importance in the online mode of learning. The learners need to be technophilic in a way to learn the different tools and skills for the online teachinglearning. Digital preparedness is very much essential for the effective teaching learning processes. The readiness for adoption of online mode of teaching is much better in the developing countries rather than 3rd world countries. That is why, in the West, the effect of online teaching is better than developing countries like India. A successful online learner is one, who loves to explore the techniques and training of different platforms and be a technophilic rather than run away from the system. The growth of online learning is very much substantial, US $\$ 18.26$ billion investment was done by 2019 , and well before the COVID-19 pandemic and it is expected the US\$316 investment in the online teaching learning market will be made by 2025. Therefore, it is a clear impression that the development of online teaching modules was well before that the COVID-19 pandemic, and only those countries made a successful transition towards online teaching, which were well prepared.

\section{Research Objectives}

1. To investigate the challenges faced by students, teachers and parents in using the online mode of teaching/learning during COVID-19.

2. To study the perspectives of the stakeholders about online teaching/learning as an alternative mode of learning during the COVID-19.

\section{Methodology}

The aim of this study is to understand various issues, challenges and advantages of online teaching from the point of view of teachers, students and parents as an alternative mode of education in COVID-19 crisis when educational activities remain suspended in educational institutions. The quantitative study used questionnaires as a survey instrument for data collection. We have used web based questionnaires for an easy and an appropriate method of collecting the data at the time of pandemic 
to ensure social distancing. Data was collected from all the stakeholders of online education, i.e. students, teachers and parents. While collecting data with the help of questionnaires, we have used a combination of close ended multiple questions, Likert scales and open ended questions. Fig. 1 shows the linkage of different stakeholders of the online teaching learning in the form of the schematic diagram.

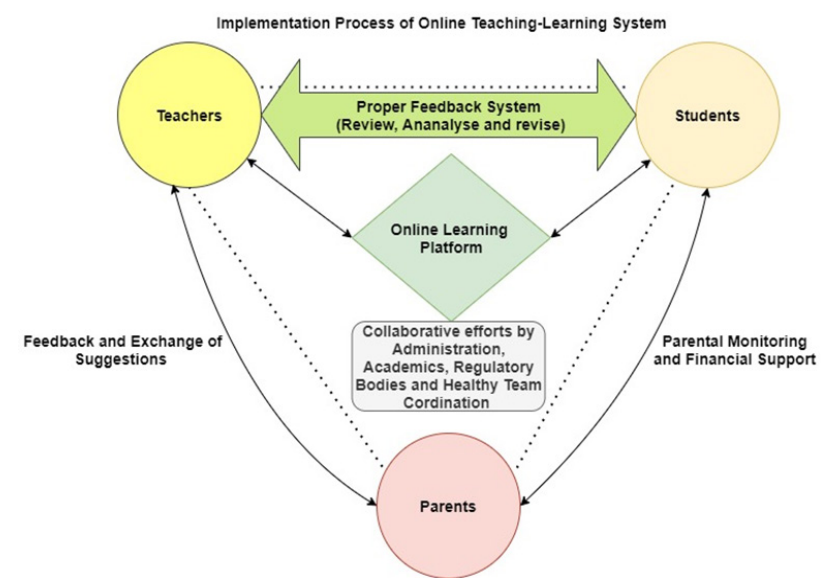

Figure 1: Schematic diagram about the framework of online teaching/ learning.

\subsection{Survey Instrument}

The survey instrument (questionnaire) was used for collection of data. The responses were collected using web based questionnaire and analyzed to study the perceptions and challenges of the teacher, students and parents regarding the online education.

The survey was released in the 1 st week of November 2020 and was available for twenty five days to accept responses from the respondents. No incentives were offered to participate in the survey. Name of the respondent was kept optional to respect the privacy of the respondents who wanted to remain anonymous while answering questions and to avoid bias on the basis of social desirability during the survey.

\subsection{Population}

The total of 2870 respondents participated in the survey. Out of which 1830 were teachers, 750 were students and 290 were parents.

\subsection{Data Analysis}

The questionnaire was divided into four sections. Section 1 contains demographic information (name, age, gender and other related information); section 2 was used to assess infrastructural availability required for online learning/teaching, section 3 was used to study perceptions regarding online teaching-learning, section 4 to study the issues and challenges faced by respondents during online learning/teaching. The questionnaire consisted of a total of 24 questions out of which 22 closed ended questions and 02 open ended questions. The students were asked to rate their experiences using a Likert scale according to the following scale: - 1-Strongly Agree, 2-Agree, 3-Disagree, 4-Strongly disagree. The demographic data like gender, email address and name was collected from the respondents participating in the survey.

The respondents were asked to record their views regarding online education during the COVID-19 in the given questionnaire. All the questions were not mandatory to answer.

All the data collected was organized, cleaned and then analyzed using proper methods. The data analysis uses the frequency procedure to tabulate the counts and calculate the percentages of responses. The quantitative data is represented in the tabular form given in Table 1.

\section{Results and Discussion}

Table 1: Displays the percentages of the responses collected during the survey

\begin{tabular}{|c|c|c|}
\hline S.No. & Survey Question & Percentage \\
\hline 1. & $\begin{array}{l}\text { Availability of Basic infra- } \\
\text { structure like Smartphone/ } \\
\text { laptop and reliable access to } \\
\text { the internet }\end{array}$ & $\begin{array}{l}\text { Yes }-87.1 \% \\
\text { No }-14.7 \% \\
\text { Not Sure }-8.2 \%\end{array}$ \\
\hline 2. & $\begin{array}{l}\text { Have you used online mode } \\
\text { of teaching/learning before } \\
\text { COVID-19? }\end{array}$ & $\begin{array}{l}\text { Yes }-14 \% \\
\text { No }-81 \% \\
\text { Not Sure }-5 \%\end{array}$ \\
\hline 3. & $\begin{array}{l}\text { Online learning is more } \\
\text { difficult than classroom } \\
\text { learning. }\end{array}$ & $\begin{array}{l}\text { Agreed }-23.6 \% \\
\text { Strongly agreed - } \\
48.9 \% \\
\text { Not agreed }-27.5 \%\end{array}$ \\
\hline 4. & $\begin{array}{l}\text { Students facing technical } \\
\text { difficulties in accessing } \\
\text { online learning platforms. }\end{array}$ & $\begin{array}{l}\text { Yes }-63.7 \% \\
\text { No }-32.3 \% \\
\text { Not Sure }-4 \%\end{array}$ \\
\hline 5. & Internet connectivity issues. & $\begin{array}{l}\text { Yes }-78.9 \% \\
\text { No }-15.1 \% \\
\text { Not Sure }-6 \%\end{array}$ \\
\hline 6. & $\begin{array}{l}\text { Teachers facing technical } \\
\text { issues in creating disseminat- } \\
\text { ing and delivering e-content }\end{array}$ & $\begin{array}{l}\text { Yes }-76.7 \% \\
\text { No }-18.3 \% \\
\text { Not Sure }-5 \%\end{array}$ \\
\hline 7. & $\begin{array}{l}\text { Teaches feel that creating } \\
\text { an e-content is more time } \\
\text { consuming and difficult }\end{array}$ & $\begin{array}{l}\text { Yes }-78.8 \% \\
\text { No }-21.2 \% \\
\text { Not Sure - } 0 \%\end{array}$ \\
\hline 8. & $\begin{array}{l}\text { Teachers feel that students } \\
\text { are not serious about online } \\
\text { learning }\end{array}$ & $\begin{array}{l}\text { Yes }-67.2 \% \\
\text { No }-25.8 \% \\
\text { Not Sure }-7 \%\end{array}$ \\
\hline 9. & $\begin{array}{l}\text { Parents find it difficult to } \\
\text { guide children in learning } \\
\text { online }\end{array}$ & $\begin{array}{l}\text { Yes }-78.2 \% \\
\text { No }-13.6 \% \\
\text { Not Sure }-8.2 \%\end{array}$ \\
\hline
\end{tabular}




\begin{tabular}{|c|l|l|}
\hline 10. & $\begin{array}{l}\text { Online learning has } \\
\text { resulted in extra } \\
\text { investment in terms of } \\
\text { digital devices like tablets, } \\
\text { smart phones, laptops, PCs } \\
\text { and internet packs etc. }\end{array}$ & $\begin{array}{l}\text { Yes - 63.1\% } \\
\text { No - 36.9\% }\end{array}$ \\
\hline 11. & $\begin{array}{l}\text { Parents need constant } \\
\text { monitoring of wards } \\
\text { during online learning. }\end{array}$ & $\begin{array}{l}\text { Yes - } 77.6 \% \\
\text { No }-23.3 \%\end{array}$ \\
\hline 12. & $\begin{array}{l}\text { Parents Claim online }-9.1 \% \\
\text { teaching is effective for } \\
\text { overall development of } \\
\text { children. }\end{array}$ & $\begin{array}{l}\text { Yes - } 76.3 \% \\
\text { No - 23.7\% }\end{array}$ \\
\hline 13. & $\begin{array}{l}\text { Parents are reluctant to send } \\
\text { their children to schools. }\end{array}$ & $\begin{array}{l}\text { Yes - 78.9\% } \\
\text { No - 21.1\% }\end{array}$ \\
\hline 14. & $\begin{array}{l}\text { Effectiveness of online } \\
\text { learning. }\end{array}$ & $\begin{array}{l}\text { Agreed - 47\% } \\
\text { Strongly agreed - } \\
36 \% \\
\text { Not agreed - 17\% }\end{array}$ \\
\hline
\end{tabular}

a. Availability of basic infrastructure like smartphone/ laptop and reliable access to the internet

When respondents were asked about availability of basic infrastructure required for online teaching/learning, e.g. digital devices like PC, laptop, smart phone and continuous access to the internet, $87.1 \%$ replied with YES, $8.2 \%$ were NOT SURE and $14.7 \%$ replied with NO.

b. Have you used online mode of teaching/learning before COVID-19?

When asked, $81 \%$ of the teachers/students responded that they are using the online mode of teaching for the first time while as $14 \%$ responded that they have already used this platform and $5 \%$ were not sure.

c. Online learning is more difficult than classroom learning

When students were asked whether they find it difficult to study online rather than in traditional classrooms, most of them, i.e. $48.9 \%$ strongly agreed to the fact, $23.6 \%$ agreed that it is more difficult and $27.5 \%$ did not agree that it is more difficult than classroom learning.

d. Students facing technical difficulties in accessing online learning platforms

$63.7 \%$ of the students reported that they faced technical difficulties in accessing online learning platforms, 32.3\% didn't face technical issues and $4 \%$ were not sure about their answer.

e. Internet connectivity issues

$78.9 \%$ of the respondents reported internet connectivity issues during the online teaching/learning sessions while as $15.1 \%$ didn't face connectivity issues and $6 \%$ were not sure.

f. Teachers facing technical issues in creating disseminating and delivering e-content

When asked whether they faced technical issues in creating, disseminating and delivering online teaching content $76.7 \%$ teachers replied with YES $18.3 \%$ replied with $\mathrm{NO}$ and $5 \%$ were NOT SURE.

g. Teaches feel that creating an e-content is more time consuming and difficult

$78.8 \%$ teachers feel that creating an e-content is more time consuming and difficult, but $21.2 \%$ don't feel like this.

h. Teachers feel that students are not serious about online learning

When teachers were asked about the seriousness of students in online learning most of the teachers, i.e. $67.2 \%$ replied with YES, 25.8\% NO, 7\% were NOT SURE.

i. Parents find it difficult to guide children in learning online

78.2\% parents replied with YES when asked whether they find it cumbersome to guide children while learning online while as $13.6 \%$ replied with $\mathrm{NO}$ and $8.2 \%$ were NOT SURE.

j. Online learning has resulted in extra investment in terms of digital devices like tablets, smart phones, laptops, PCs and internet packs etc

$63.1 \%$ of the parents agreed to the fact that they have made the extra investment in the purchase of digital devices or subscription to Internet packs/broadband facilities to ensure uninterrupted internet facility to the children required for learning online and $36.9 \%$ replied otherwise.

k. Parents need constant monitoring of wards during online learning

When asking parents, whether they have to constantly monitor their children during online learning, $77.6 \%$ parents replied with YES, 23.3\% replied with NO and $9.1 \%$ were NOT SURE.

1. Parents Claim online teaching is not effective for overall development of children

When asked, $76.3 \%$ parents were of the opinion that online teaching can help in enhancing subject knowledge, but cannot contribute to the overall development of the children but $23.7 \%$ think otherwise.

m. Parents are reluctant to send their children to schools

When the parents were asked about their willingness that should schools at this stage most of the parents, i.e. $78.9 \%$ responded negatively and only a small percentage i.e. $21.1 \%$ wanted schools to reopen.

n. Effectiveness of Online Learning

When the respondents were asked what they feel about the effectiveness of online learning, $47 \%$ strongly agreed on its effectiveness, $36 \%$ agreed it is effective and $17 \%$ disagreed on its effectiveness. 
The transition of formal education pedagogical approach towards the online approach seems to be the new normal amid COVID-19 Pandemic. One of the buzzword during the ongoing pandemic was a webinar (Online seminar). Initially people were hesitant to attend webinars. But now, it is one of the commonest academic components of an online mode and a good participation is observed. Govt. of India has made online teaching mandatory in the higher education. The apex bodies like UGC and AICTE have directed to deliver 25\% syllabus through online mode even after the COVID-19 pandemic is over. In the latest notification by the UGC, the promotion of teachers in the higher educational institutes shall be also be evaluated on the role of teacher in the digital literacy.

\subsection{Benefits of Online Learning}

- Online learning leads to the development of self study skills in students.

- It focuses on the student centered approach to teaching.

- It provides freedom of space and time to the learners.

- It uses a flexible approach of learning.

- Its self paced learning. Learning speed can be adjusted to suit the learner speed of learning.

- It leads to the development of digital literacy skills.

- Online learning/teaching is costing more effective than its counterparts.

- Online learning provides customized experience of learning by personalizing the learning environment to suit the learners needs based on their feedback.

- It provides opportunities for communication/ collaboration with peers and experts around the world.

- Simulation can be used as an alternative method to illustrate scientific experiments in science or engineering fields[29].

\subsection{Challenges}

- Student participation is a challenge in online teaching. Teachers complain that some percentage of students don't turn up for online classes in spite of continuous efforts made by teachers. In some cases, students are participating to the extent that they only log in to the classes via registered devices, but don't actually listen attentively or participate actively in the online classes.

- There is no direct control of teachers over the students.

- Teachers report problems in assembling students on an online platform. The contact details of students are sometimes incorrect; some students remain untraceable until the later stages of the classes.

- Teachers are not well prepared, don't test their strategies to work out which tools or methods suit them best, they don't have a plan B in case of any technical glitch during the lectures.

- $\quad$ Some teachers or schools are in a hurry to complete the syllabus without building the skills of students and taking feedback from students ignoring the real goal of education.

- Lack of cooperation from parents of students, particularly belonging to disadvantaged sections of the society who are illiterate or unaware about the online mode of teaching/learning.

- The student involvement in the online classes has been noticed not up to the mark due to certain reasons like not getting eye to eye contact with the teacher, not habitual to these new normal and sometimes technical issues like network speed causes distraction mainly owing to poor connectivity.

- Students are not taking an online mode of learning seriously because of absence of continuous direct monitoring of the teachers and absence of two ways interaction between a student and a teacher is actually happening on the ground level. Even it has been found that some teachers are less seriously interested in delivering online classes.

- Students feel alienated from other students and the feeling of learning in a group and enjoying learning together similar to physical classroom is missing in virtual classrooms.

- The home environment is not suitable for learning as there are a lot of distractions from the surroundings.

- Lack of direct communication makes it difficult for students to understand the assignments properly given by teachers and thus students feel frustrated in completing these assignments.

- Lack of face to face interaction is one of the main reasons leading to the disinterest of students in the online mode of teaching/learning, with the result the respective course outcome is not achieved effectively.

- Lack of ICT infrastructure in Education institutes of $\mathrm{J} \& \mathrm{~K}$. The adequate level of digital infrastructure is very much required for the efficient execution of online teaching-learning. Most of the schools in India lack electricity connections, high speed internet connectivity and devices like computers, tablets required for online teaching/learning [30].

- Digital literacy of teachers is below normal; especially the teachers above the age of 50 do not feel comfortable with online mode of teaching. Older teachers are less motivated in learning the new technologies pertaining to the online teachinglearning.

- Lack of training/guidelines to use the online mode 
of learning. Arrangement of necessary training is the need of hour to make the online teaching at a grass root level, but very less or no extensive training is provided to the teachers about the use of online mode of teaching. Most of the teachers feel the need of trainings/guidelines to help them create, disseminate digital content and teach online [31].

- There are various subjects, where digital content is not available or a small amount of low quality digital content is available on certain subjects.

- Curriculum does not support online learning. The apex body of higher education, i.e.; UGC has recently issued guidelines for $25 \%$ completion of the syllabus through online mode. But, it is not mandatory in the school education as of now.

- Practical experiments cannot be conducted online. The experimental learning is of prime importance, especially with regard to science and engineering courses and is considered the basic building blocks of real learning. Through online mode of learning except certain courses like computer science, the actual practical experimentation is not possible as of now. But, there are simulators for an alternate method for the practical work. The computer science engineering is so advanced at present that simulators are almost possible in every course/subject.

- Lack of experience in handling digital mode of teaching/learning. The experience comes with time after practicing the things in letter and spirit, the reluctance towards digital literacy is the reason of not producing expert human resource at every where[32].

- Copyright issues in creating digital content and lack of awareness in teachers about it. The creation of digital content is equally important in the online teaching, learning as the dissemination of content. The verifiable and authentic content production needs complete awareness about legal issues of software and its usage. Apart from the copyright issues, the sincere efforts must be taken into account by the content producer to create the authentic content and it should be screened before putting in the cloud for students[33].

- Teaching children with disabilities or special needs online can be quite challenging and reports suggest that parents having differently abled children are finding it more difficult to cope with online learning during the pandemic. As per the State of Education report for India, year 2019 the number of children with disabilities in India is 7,864,636 and $61 \%$ of this number is of the age group 5-19 and are enrolled in educational institutions across India. These include children with hearing, speech, developmental and intellectual impairments who cannot be taught in absence of special educators experienced to handle such children [34-35].

- Overall development of children has suffered during the pandemic: there is no doubt about the ill effects of COVID-19 pandemic on the overall development of the children apart from the teaching-learning. The sports activities were restricted and it forced the children to go on virtual sports online, that adversely affected the young minds and made them addicted to the virtual games. Although, there is no harm if the virtual sports are practiced in an absolute limited timeframe, it will then enhance the analytical skills and sharpness of the mind.

- Increased screen time has adversely affected vision and physical health of children. The present study from the various corners of the globe about the excessive screen time has come up with this conclusion that more screen time leads to many health and psychological troubles in the humans like weakens the eye sight, headache, anxiety, depression, short temperedness, social disconnect in reality and more virtual connect[36].

- Parental monitoring is necessary to keep an eye on the online activities of children to prevent them from online predators, bad companies that can drag them to drugs, theft, criminal activities, risky internet behavior, etc [37].

- As most of the educational institutions had to conduct exams for this session 2020-21 online, students misused the opportunity of online assessment during the pandemic by cheating even in the presence of proctoring technologies used to prevent such instances.

- Some percentages of students don't have a positive attitude towards online teaching/learning and thus find it difficult to study online.

- Slow internet connectivity, particularly in remote areas poses problems in video streaming of live lectures, uploading, downloading of large media files like images, videos etc[38].

- Face to Face learning is compulsory for practical areas of science, skill development, physical activities, sport, etc and cannot be taught online.

- There is a lack of proper planning on the part of teachers for online classes.

- Teachers working from home faced distractions from family members, children etc.

- $\quad 1.26$ million students are enrolled for a mid day meals scheme in India that was started in 1995 leading to adverse effects on nutrition of poor students who already find it hard to feed themselves with the increased unemployment post COVID-19. 
- One of the challenges even in the post COVID-19 period would be to maintain balance between the online and offline mode.

\section{Assessment and Evaluation through Online Mode}

As we know, that examination is the most sensitive and integral part of the education system. One of the important parameters of defining the standard of any educational institution is its method and process of the examination system. During the ongoing COVID-19 pandemic, the assessment and evaluation of the students has also been done through the available online modes. Most of the examinations either offline or online are conducted under a proctored atmosphere. The examinations held during COVID-19 have been held through online modes, but to ensure the social distancing students were allowed to appear for the respective examinations from their homes. It is evident that to a substantial degree, the impersonation and unfair means was neglected. Even though there are various proctored platforms available for the examination, the fairness was not ensured cent per cent. In some of the places, where network speed was the major concern, the examination was held through Google forms. In Jammu and Kashmir due to security reasons, the $2 \mathrm{G}$ network is working and most proctored examination tools, which are based on an artificial intelligence framework, are not compatible with the $2 \mathrm{G}$ network. The Google form was explored for the assessment and evaluation. Although the viva-voce is conducted through video conferencing and is meeting its basic essence. The conduct of free and fare examination through the online mode is still a challenge. If the online examination is held at the designated computer centers under the manual supervision, the fairness can be ensured to the maximum tune. The subjective type of examination involves a complex process rather than objective type of examination.

Above all, the important concern about the implementation of online-teaching is accountability and monitoring. After taking surveys from many institutes of the country, it has been observed that the monitoring was found not up to the mark. The monitoring assignment was the left at the discretion of the teacher and trust of the teacher about his commitment towards the job. The institute where customized learning management systems (LMS) are installed, the monitoring was very much accountable and effective. In using an LMS, a separate user account is given to teachers and students and the usage is centrally monitored. It has also been observed that after asking progress about online teaching for the teachers, in some cases the fudged data were produced. Although, there is a great scope of developing new techniques for the online teaching-learning techniques with regard to monitoring, assessment and dissemination of content. The people, who have good soft skills, are more inclined towards virtual classes. Initially, the shift over online teaching-learning was not promising, but now the quest about the online platforms among the learners have shown a paradigm shift[39-41].

\section{Platforms}

LMS (Learning Management Systems) is the specific online solutions for creating, disseminating and delivering e-content for teaching/learning.

Taking into consideration the technical issues faced by teachers in using online platforms for teaching, has prevented educational institutions to use best online tools with sophisticated features for online teaching. Ease of use remains the main feature in focus while selecting the platform for online teaching/learning, the reason being different levels of digital literacy of teachers as well as students.

There are a lot of platforms available, some are paid, some are available free of cost.

The most common platforms used in different parts of the world such as Otus, Floop, VizlQ, Ginzy, Kami, G Suite, Pluralsight, Shift, Hapara, Kialoedu, start.me, Classtime, Ted-Ed, Google Classroom, Pronto, Class Dojo, Parlay, Classwize, Coursera, Zoom, EDX, Google Meet, Lactora Inspire, Bonci, Articulate360, Future Learn, Elucidate, Seesaw, Adobe Captivate, Udemy, Wevideo. Blackboard Learn, Edmodo, Neo, Gogaurdian, Flipgrid, codaa-cademy, Lan School, Bak-pax, Skillshare and many more. The strength of these platforms is, they are user friendly and most of them are open source and free applications. In different parts of the globe, these platforms are immensely used as per the comfort of the learner. Zoom and Google Meet is the most commonly used platforms for the video conferencing and live video classes. The cost of subscription is also affordable and these are secure and reliable softwares. They are also compatible with the Android Operating Systems. There is a lot of scope for the developers to make use of the code of open source and free online tools and customize them as per the specific requirements of the learners of a particular region or place. The majority of the online teaching-learning tools are easy to install and use. All the features of the traditional classroom teaching are imbibed in the virtual tools like attendance, sharing of notes, discussion features, examination features and many more. The recording of the online classes can be used for future use and even the absent students are able to watch it later on in the asynchronous mode. If any student has missed the class or did not understand any concept, he/ she can rewind these classes available in the archive.

The most widely used applications for delivery of content to students by teachers is WhatsApp application. 
The main reason being familiarity and moreover, it can be used in slow network connection also. This application is easy to use and is already popular with people to share documents and media with each other. The WhatsApp has a feature to create groups which help in creating a shared space to share information and media with people connected in a group. It helps in coordination and interaction of teachers, students and parents added to the same group. Although there is also option for video calls and video documentation, but lack of sophisticated features makes it less suitable for live teaching/interaction between teachers and students.

Zoom is widely used for conducting live meetings, webinars and delivering online lectures by teachers in India. Technical configurations in online teaching platforms make it a little bit difficult for teachers having little computer skills to use. Platforms like Zoom, Google Meet etc are easy to use, intuitive, work well on $2 \mathrm{G}$ networks with little or no issues [42].

People are wondering whether this transition is temporary or permanent, will online teaching/learning continue post pandemic, or it will lose its zeal as soon as the situation returns back to normal, but experts suggest that it may be the new normal and some changes that resulted in the education sector because of COVID-19 may never be reversed again.

\subsection{Govt Initiatives}

In response to COVID-19 crisis Indian National Commission, in cooperation with UNESCO (INCCU) has started some initiatives to promote digital learning during the pandemic and reach out to remote learners. The government gave a serious thought over the implementation of digital learning at the grass root level. The availability and affordability are the two main concerns, especially for the learners in the remote areas with poor financial health. Some of the appreciable and good initiatives taken by the Government of India include:-

1. SWAYAM: Study Webs of Active Learning for Young Aspiring Minds is a program on Massive Open Online Courses (MOOCs) platform hosting online courses in various spheres. The three basic principles of education policy viz, access, equity and quality need to be achieved through various schemes and programs. SWAYAM is one of the leading initiatives towards the bridging of the digital divide. The best teachers of the country came forward to help in developing the quality content in various courses ranging from 9th standard to the postgraduate level. To ensure the best quality and its proper delivery to the interested learner, the Govt. of India has appointed nine coordinators for this important task. These coordinators are AICTE, UGC, NITTTR,

\section{CEC, NCERT, IGNOU, IIMB, NPTEL, and NIOS}

2. SWAYAM PRABHA: There are thirty four DTH channels exclusively meant for telecasting educational programs with very good quality using a GSAT-15 satellite on $24 \times 7$ patterns. Keeping in view the learner's convenience, 4 hours of new content are at least 5 times telecasted every day. The content available on the SWAYAM PRABHA is provided by various reputed institutions of the country, including NIOS, IITs, NPTEL, IGNOU, UGC, NCERT and CEC.

2. DIKSHA: It is the DIGITAL INFRASTRUCTURE FOR SCHOOL EDUCATION managed by the National Council of Educational Research and Training initiated by the Ministry of Education, Govt of India. This is available as an App; its objective is to engage the teachers, students and parents with the learning material with reference to the prescribed school curriculum.

3. NISHTHA: National Initiative for School Heads' and Teachers' Holistic Advancement is a programme for capacity building for improving the quality in the school education through integrated teacher training. The prime objective of this programme is to improve the competencies in the teachers, principals of the schools. The implementation of these initiatives is carried on at state, district, block and cluster levels through integrated manner, so that the learning outcomes can be obtained.

5. NATIONAL DIGITAL LIBRARY: The e-trace of almost all the books have been generated and made available at various digital libraries through an organized manner. The Ministry of Education, Govt. of India has arranged the adequate amount of funding for a project National Digital Library of India (NDLI) to make a single window for accessing the learning material especially e-books to the student community. It is the virtual repository of the learning material integrated with many services. The learners can get the required learning material in less time by filtering and federated search. The IIT Kharagpur has been looking into this major initiative.

6. e-PATSHALA: One of the important initiatives by MHRD, Govt. of India towards promoting, improving and providing training to the learner community. It is basically a learning portal or mobile app hosting, econtent of textbooks, audio-video lectures and has been kept free of cost for the student community. A student has to register on the e-Pathshala portal and can make use of it.

7. ARPIT: On November 13, 2018 MHRD, Govt. of India has launched a program for the professional development, especially for teachers in higher education using SWAYAM platform. It is a continuous ongoing 
module and the evaluation and assessment of the trainee is done by the National Testing Agencies [4ㄱ] .

Although teachers and students are eagerly waiting for schools to reopen and normalcy to return in school activities, virtual classes have been successful to maintain a connection between teachers and students at the time of social distancing.

Even though the government has made decisions about reopening of schools at secondary and higher levels after considering the willingness of the students, most of the parents are concerned about the health of children and are not ready to send their children to school yet.

A second wave of COVID-19 and identification of new mutated covid strain in some countries like UK, Denmark, Australia, Netherlands with increased transmission rate almost $56 \%$ more than its previous variant and projection of the increased mortality rate has led to fresh restrictions in some parts of the world. This has also increased uncertainty and fear of COVID-19 in people who had pinned their hopes for emerging vaccines for the virus [43].

With uncertainty prevailing about when the COVID-19 is going to end, no major breakouts in vaccines for COVID-19 and emergence of new mutated COVID-19 strain in some countries leading to fresh lockdowns in some parts of the world, online teaching/ learning is the only possible replacement for classroom teaching and there is no other possible alternative to teach students in the current situation to continue the process of teaching/learning.

\section{Conclusion}

In response to the situation that arisen due to months long closure of schools, colleges and universities unplanned and instant migration to digital platform took place. Although online learning is not as effective as classroom learning, but to the large extent it has helped teachers and students to continue the learning process and assessment in the COVID-19 crisis when the conventional education system almost collapsed. Unreliable internet access is a major hurdle in online learning in our country and particularly in areas like J\&K. COVID-19 has exposed weaknesses in our education system and shown that ICT infrastructure in India needs major revamping along with professional development of teachers and digital literacy in focus. Internet access must be affordable and within the reach of all, irrespective of spatial divisions. We need to promote online teaching/learning even after the end of the pandemic and focus on building ICT infrastructure in educational institutions at all levels particularly in schools. Teachers must be trained to use ICT devices and online platforms for successful integration of ICT in the teaching/learning process. Although our research study has some limitations like self reporting, small sample size and nonrandom selection, but still it provides a brief idea about the online learning/teaching scenario in the country amidst COVID-19 crisis. The future scope of the study can include a larger sample size and random selection to generate more accurate results.

\section{References}

[1] Worldometer. Coronavirus Cases. Worldometer, 2020. [Online]. Available: https://www.worldometers. info/coronavirus/. [Accessed: 20-Jul-2020].

[2] WHO. Coronavirus disease (COVID-19). [Online]. Available:https://www.who.int/emergencies/ diseases/novel-coronavirus-2019. [Accessed: 27Jul-2020].

[3] L. Mishra, T. Gupta, and A. Shree. Online teachinglearning in higher education during lockdown period of COVID-19 pandemic. International Journal of Educational Research Open, vol. 1, p. 100012, 2020. https://doi.org/10.1016/j.ijedro.2020.100012

[4] UNESCO. Six key messages on the protection of the right to education of people in situations of mobility in the context of COVID-19. [Online]. Available: https://en.unesco.org/news/six-key-messagespeople-mobility-covid-19. [Accessed: 28-May2020].

[5] UNESCO. School closures caused by Coronavirus (Covid-19). [Online]. Available: https://en.unesco. org/covid 19/educationresponse. [Accessed: 31Dec-2020].

[6] Business Standard. 1.54 bn students out of school over Covid-19; girls to be worst hit: Unesco | Business Standard Nerws. [Online]. Available: https://www. business-standard.com/article/current-affairs / 154-bn-students-out-of-school-over-covid-19-girlsto-be-worst-hit-unesco-120042200741_1.html. [Accessed: 28-May-2020].

[7] S. Gouda M and D. T. Sekher. Factors leading to school dropouts in India: An analysis of national family health survey-3 data. International Journal of Research $\Xi^{2}$ Method in Education, vol. 4, no. 6, pp. 7583, 2014. https://doi.org/10.9790/7388-04637583

[8] UNESCO. 1.37 billion students now home as COVID-19 school closures expand, ministers scale up multimedia approaches to ensure learning continuity. [Online]. Available: https://en.unesco.org/news/137-billionstudents-now-home-covid-19-school-closuresexpand-ministers-scale-multimedia. [Accessed: 05Jun-2020].

[9] R. H. Huang, D. J. Liu, A. Tlili, J. F. Yang and H. H. Wang. Handbook on facilitating flexible learning during educational disruption: The Chinese experience in maintaining undisrupted learning in COVID-19 Outbreak. Smart Learn. Inst. Beijing Norm. Univ. 
UNESCO, pp. 1-54, 2020.

[10] UNESCO. Over $154 \mathrm{cr}$ students hit by schools, colleges closure due to COVID-19; girls to be worst hit - Times of India. [Online]. Available: https://timesofindia. indiatimes.com/home/education/news/unsecoover-1 54-cr-students-hit-by-schoolscollegesclosure-due-to-covid-19-girls-to-be-worst-hit/ articleshow/75294123.cms?. [Accessed: 28-May2020].

[11] C. Rapanta, L. Botturi, P. Goodyear, L. Guàrdia, and M. Koole. Online university teaching during and after the COVID-19 crisis: Refocusing teacher presence and learning activity. Postdigital Science and Education, vol. 2, no. 3, pp. 923-945, 2020. https://doi.org/10.1007/s42438-020-00155-y

[12] D. Bansal. Benefits of ICT in education challenges of ICT enabled education at school and home. Bhartiyam International Journal of Education $\Xi^{\circ}$ Research, vol. 5, no. 2, pp. 1-8, 2016.

[13] Vikaspedia. Teachers, Teaching and ICTs vikaspedia. [Online]. Available: https://vikaspedia. in/education/teachers-corner/teachers-teachingand-icts. [Accessed: 19-May-2020].

[14] S. Ghavifekr, T. Kunjappan, and L. Ramasamy. Teaching and learning with ICT tools: Issues and challenges from 'Teachers' perceptions. Malaysian Online Journal of Educational Technology, vol. 4, no. 2, pp. 38-57, 2006.

[15] J. König, D. J. Jäger-biela, and N. Glutsch. Adapting to online teaching during COVID-19 school closure: teacher education and teacher competence effects among early career teachers in Germany. European Journal of Teacher Education., vol. 43, no. 4, pp. 608622, 2020.

https://doi.org/10.1080/02619768.2020.1809650

[16] S. Ghavifekr, A. Zabidi, A. Razak, M. F. A. Ghani, N. Yan, and Y. Meixi. ICT Integration In Education: Incorporation for Teaching \& Learning Improvement. The Malaysian Online Journal of Educational Technology, vol. 2, no. 2, 2012.

[17] L. Mishra, T. Gupta, and A. Shree. Online teachinglearning in higher education during lockdown period of COVID-19 pandemic. International Journal of Educational Research Open, vol. 1, p. 100012, Sep. 2020 .

https://doi.org/10.1016/j.ijedro.2020.100012

[18] U. Tandon. Factors influencing adoption of online teaching by school teachers: A study during COVID-19 pandemic. Journal of Public Affairs, pp. 1-11, 2020. https://doi.org/10.1002/pa.2503

[19] S. K. Howard and A. Mozejko. Teachers: Technology, change and resistance. pp. 307-317, 2015.

[20] C. P. Period and A. C. Study. The perceptions of primary school teachers of online learning during the the perceptions of primary school teachers of online learning during the COVID-19 pandemic period: A case study in Indonesia. Journal of Ethnic and Cultural Studies, vol. 7, no. 2, pp. 90-109, 2020. http://dx.doi.org/10.29333/ejecs/388

[21] J. Voogt and H. Pelgrum. ICT and curriculum change. Human Technology, vol. 1, no. 2, pp. 157-175, 2005. http://dx.doi.org/10.17011/ht/urn.2005356

[22] Tech Online. A new pedagogy is emerging and online learning is a key contributing factor | teachonline. ca. [Online]. Available: https://teachonline.ca/ tools-trends/how-teach-online-student-success / new-pedagogy-emerging-and-online-learning-keycontributing-factor. [Accessed: 25-Dec-2020].

[23] J. M. Lin, P. Wang and I. Lin. Pedagogy technology: A two-dimensional model for teachers' ICT integration _1159 97..108. British Journal of Educational Technology, vol. 43, no. 1, pp. 97-108, 2012. https://10.1111/j.1467-8535.2010.01159.x

[24] M. I. Panda, D. C. Chhatar, and B. Mharana. A brief view to digital divide in Indian scenario. International Journal of Scientific and Research Publications, vol. 3, no. 12, pp. 1-7, 2013.

[25] S. Singh. Digital divide in India: Measurement, determinants and policy for addressing the challenges in bridging the digital divide. International Journal of Innovation in the Digital Economy, vol. 1, no.2, 2018. https://doi.org/10.4018/jide.2010040101

[26] S. J. Daniel. Education and the COVID-19 pandemic. Prospects 49, pp. 91-96, 2020.

https://doi.org/10.1007/s 1 1125-020-09464-3

[27] Tribune India. Parents lose sleep over instances of misuse of mobile: The Tribune India. [Online]. Available: https://www.tribuneindia.com/news/ schools/parents-lose-sleep-over-instances-ofmisuse-of-mobile-102285. [Accessed: 25-Dec2020].

[28] Hindustan Times. Covid-19 lockdown: Amid e-learning push, parents wary as children's screen time increases - india news - Hindustan Times. [Online]. Available: https://www.hindustantimes. com/india-news / covid-19-lockdown-amid-elearning-push-parents-wary-as-children-s-screentime-increases/story-ejsLGZz5EiZCLxjThu2H3M. html. [Accessed: 05-Jun-2020].

[29] S. Appana. A review of benefits and limitations of online learning in the cContext of the student, the instructor, and the tenured faculty. International Journal on E-Learning, vol. 7, no. 1, pp. 5-22, 2008.

[30] M. M. Hassan. Perspective of students regarding online learning during the COVID-19 pandemic, Tathapi," 2020.

[31] USA Today. Coronavirus meant teachers had little training for online classes. [Online]. Available: 
https: / / ww w.usatoday.com/story/news / education/2020/04/17/coronavirus-teachers-onlineclass-school-closures/2972529001/. [Accessed: 28May-2020].

[32] L. Olsson and E. Edman-Stålbrant. Digital literacy as a challenge for Teacher. IFIP - The International Federation for Information Processing, vol 281. Springer, Boston, MA. https://doi.org/10.1007/978-0-387-09729-9_2

[33] Blogs LOC. TEACHing from a distance and copyright considerations | Copyright: Creativity at Work. [Online]. Available: https://blogs.loc.gov/ copyright/2020/03/teaching-from-a-distance-andcopyright-considerations/. [Accessed: 27-Dec2020].

[34]T. Crouse. Learning to serve students with disabilities online: Teachers' Perspectives. Journal of Online Learning Research, vol. 4, pp. 123-145, 2018.

[35] R. Armitage and L. B. Nellums. The COVID-19 response must be disability inclusive. The Lancet Public Health, vol. 5, no. 5. Elsevier Ltd, p. e257, 2020.

[36] A. Sultana, S. Tasnim, S. Bhattacharya, M. Hossain, and N. Purohit. Digital screen time during COVID-19 pandemic: A public health concern, F1000 Research, 2020.

https://doi.org/10.12688/f1000research.50880.1

[37] Council of Europe. Cybercrime and COVID-19 News. [Online]. Available: https://www.coe.int/ en/web/cybercrime/-/ cybercrime-and-covid-19. [Accessed: 05-Jun-2020].
[38] M. Adnan and K. Anwar. Online learning amid the COVID-19 pandemic: Students' perspectives. Journal of Pedagogical Sociology and Psychology, vol. 2, no. 1, pp. 45-51, 2020.

[39] M. M. Hassan and T. Mirza. Impact of ICT in changing the role of a Teacher: An overview. Gedrag E Organisatie Review. vol. 33, no. 03, pp. 441-449. https://doi.org/10.37896/GOR33.03/440

[40] M. M. Hassan and T. Mirza. An approach of cloud based mobile learning system. International Journal of Research in Advent Technology, vol. 7, no. 5, pp. 214-216, 2019.

https://doi.org/10.32622/ijrat.75201975

[41] M. W. Hussain. Impact of COVID-19 pandemic on the human behavior. International Journal of Education and Management Engineering, vol. 10, no. 8, pp. 35-61, 2020.

[42] CISO. Cyber security news: Zoom app vulnerable to cyber attacks, says CERT-India; issues advisory on safety measures, IT Security News, ET CISO. [Online]. Available: https://ciso.economictimes.indiatimes. com/news / zoom-app-vulnerable-to-cyberattacks-says-cert-india-issues-advisory-on-safetymeasures/74959554. [Accessed: 28-May-2020].

[43] Money Control. COVID-19 update | Mutated coronavirus variant $56 \%$ more transmissible than other strains, says study. [Online]. Available: https: / / www.moneycontrol.com/news / health-and-fitness/covid-19-update-mutatedcorornavirus-varient-56-more-transmissible-thanother-strains-says-study-6268031.html. [Accessed: 25-Dec-2020].

\begin{tabular}{l}
\hline Journal on Today's Ideas - Tomorrow's Technologies \\
\cline { 2 - 4 } \\
Chitkara University, Saraswati Kendra, SCO 160-161, Sector 9-C, \\
Chandigarh, 160009, India
\end{tabular}

